\title{
Two mechanisms of caspase 9 processing in double-stranded RNA- and virus-triggered apoptosis
}

\author{
M. S. Iordanov, O. P. Ryabinina, P. Schneider and B. E. Magun \\ Department of Cell and Developmental Biology, Oregon Health \& Science University, Portland, Oregon 97239 \\ (M. S. lordanov, O. P. Ryabinina, B. E. Magun); Department of Biochemistry, University of Lausanne, \\ $\mathrm{CH}-1066$ Epalinges, Switzerland (P. Schneider)
}

\begin{abstract}
Viral double-stranded RNA (dsRNA) is a ubiquitous intracellular "alert signal" used by cells to detect viral infection and to mount anti-viral responses. DsRNA triggers a rapid (complete within 2-4 h) apoptosis in the highly-susceptible HeLa cell line. Here, we demonstrate that the apical event in this apoptotic cascade is the activation of procaspase 8 . Downstream of caspase 8 , the apoptotic signaling cascade bifurcates into a mitochondria-independent caspase 8/caspase 3 arm and a mitochondria-dependent, caspase 8/Bid/Bax/Bak/cytochrome c arm. Both arms impinge upon, and activate, procaspase 9 via two different cleavage sites within the procaspase 9 molecule (D330 and D315, respectively). This is the first in vivo demonstration that the "effector" caspase 3 plays an "initiator" role in the regulation of caspase 9 . The dsRNA-induced apoptosis is potentiated by the inhibition of protein synthesis, whose role is to accelerate the execution of all apoptosis steps downstream of, and including, the activation of caspase 8. Thus, efficient apoptosis in response to viral dsRNA results from the co-operation of the two major apical caspases ( 8 and 9 ) and the dsRNA-activated protein kinase $R$ (PKR)/ribonuclease L (RNase $L$ ) system that is essential for the inhibition of protein synthesis in response to viral infection.
\end{abstract}

Keywords: apoptosis; caspases; double-stranded RNA; encephalomyocarditis virus

\section{Introduction}

Eukaryotic cells "sense" the need to mount specific responses to viral infections by recognizing the appearance of viral intermediates that are absent in naïve, uninfected, cells. A property exclusively restricted to viruses is their

This work was supported by U.S. Public Health Service Grants CA39360 and ES-08456 to B.E.M. and CA-93718 to M.S.I.

Correspondence to: B. E. Magun, Department of Cell and Developmental Biology, Oregon Health \& Science University, 3181 Sam Jackson Park Road, Portland, Oregon 97239. Tel.: 503-494-7811; Fax: 503-494-4253; e-mail: magunb@OHSU.edu ability to produce, intracellularly, copious amounts of RNA species forming double-stranded helices [reviewed in ref. ${ }^{1}$ ]. Binding of dsRNA to intracellular sensor(s) leads to an antiviral response that is comprised of two important components: a productive/alarming response coordinated by the activation of protein kinases that lead to the transcriptional activation of interferons, cytokines, and chemokines $^{2-4}$ and a destructive/suicidal response that results from engagement of an apoptotic program. ${ }^{5-10}$ The importance of apoptosis as an effective antiviral strategy is underscored by the plethora of apoptosis-suppressing proteins encoded by viral genomes [reviewed in refs ${ }^{11,12}$ ]. Furthermore, genetic evidence from mice ${ }^{13}$ demonstrates that inhibition of apoptosis by the virus is critical for the virulence of encephalomyocarditis virus (EMCV), a picornavirus that is lethal to infected mice.

Extensive investigations into the mechanisms of apoptosis ${ }^{14}$ have revealed the existence of intrinsic and extrinsic apoptosis-initiating pathways [for reviews on apoptosis, see refs ${ }^{15-21}$. In the extrinsic pathway, specialized proteinaceous extracellular death ligands (e.g., FasL, TNF- $\alpha$ ) bind to cognate death receptors (e.g., Fas, TNF$\mathrm{R} 1$, respectively) [reviewed in ref. ${ }^{22}$ ]. The cytoplasmic portions of death receptors recruit "adaptor" proteins such as the Fas-associated protein with death domain (FADD, also known as MORT1). ${ }^{23,24}$ The recruitment of FADD leads to the subsequent recruitment of a dormant protease, referred to as procaspase 8, FLICE, or MACH. ${ }^{25,26}$ The resulting multiprotein complex containing FasL, Fas, FADD, and procaspase 8 is known as the death-inducing signaling complex (DISC). ${ }^{27}$ The increased local concentration within the DISC of the procaspase 8 allows for its spontaneous autocatalytic cleavage and activation by "induced proximity". ${ }^{28}$

In the intrinsic apoptotic pathway, various signals (usually generated by cellular stress) converge on, and compromise, the capability of the outer mitochondrial membrane to remain impermeable to cytochrome c [reviewed in refs ${ }^{29-31}$. Once released from mitochondria into the cytosol, cytochrome c becomes a positive regulator of the 
apoptosome, ${ }^{32,33}$ a sevenmeric complex of the protein APAF1 (apoptotic protease-activating factor 1) bound to another dormant protease referred to as procaspase 9, ICELAP6, or Mch6. ${ }^{34,35}$ Similar to procaspase 8, the "induced proximity" of procaspase 9 triggers its own autocatalytic processing and activation. ${ }^{33,36}$

Caspases 8 and 9 are referred to as "initiator" or "apical" caspases [reviewed in refs ${ }^{37,38}$ ]. Initiator caspases exert their functions predominantly by activating (through targeted proteolysis) downstream caspases with (referred to also as "effector", or "executioner", caspases). These include caspases 3, 6, 7, and, possibly, $14 . .^{37,38}$ In general, all procaspases undergo activation via two successive proteolytic events: first between the large and the small subunits and then between the large subunit and the prodomain. ${ }^{37,38}$ The active tetrameric enzymes are composed of two dimers, each dimer consisting of one cleaved large and one cleaved small subunit. ${ }^{37,38}$ The proper functioning of the active caspase at a different cellular location may require the cleavage of the prodomain and release of the active enzyme from its "anchor". Once activated by the initiator caspases, effector caspases dismantle the apoptotic cell by systematically cleaving more than 100 cytoplasmic and nuclear substrates, thus interfering with virtually every cellular function. Based on the consensus cleavage sequence DEVD (the arrow represents the cleavage occurring $\mathrm{C}$-terminally of the aspartic acid residue in $\mathrm{P}_{1}$ position) for the effector caspases 3 and 7 found in the abundant caspase substrate poly(ADP)ribose polymerase (PARP), these two caspases are sometimes referred to as DEVDases. ${ }^{37,38}$

The activation of procaspase 8 can activate the apoptotic program both by direct cleavage of procaspase 3 and by provoking the release of cytochrome $\mathrm{c}$ from $\mathrm{mi}-$ tochondria. The mitochondrial arm activated by caspase 8 is initiated by the cleavage of Bid, a free cytosolic protein, to $\mathrm{a} \sim 15 \mathrm{kDa}$ truncated form, $\mathrm{tBid}^{39,40} \mathrm{tBid}$ translocates to mitochondria ${ }^{39,40}$ and, in collaboration with either Bax or Bak (two pro-apoptotic Bcl-2 family members), triggers the release of cytochrome $c$ from mitochondria. ${ }^{41}$ In non-apoptotic cells, Bax is a cytosolic protein, which, in response to cleavage of $\mathrm{Bid}$, inserts into the outer mitochondrial membrane where it forms an oligomeric channel of poorly understood conductance. ${ }^{42}$ Unlike Bax, Bak is constitutively associated with mitochondrial membranes. ${ }^{43-46}$ Upon stimulation with proapoptotic agents, Bak is "activated" (also via oligomerization and channel formation) and its association with mitochondrial membranes is altered, although the mechanisms of this alteration are poorly understood $[43-45,47$ this work].

In this work, we employed HeLa cells to dissect the apoptotic mechanisms that mediate the activation of caspase 9 in response to dsRNA. We demonstrate that caspase 8 (previously implicated in the initiation of dsRNA- induced apoptosis) $)^{5,48}$ is positioned upstream of caspase 9 in the genesis of the dsRNA-triggered apoptotic signal. Unexpectedly, we observed that the caspase 8-activated DEVDase caspase 3 appears to process caspase 9 at aspartic acid residue $\mathrm{D} 330$ in a way that kinetically precedes the cytochrome c-stimulated autocatalytic processing of caspase 9 at aspartic acid residue D315. To our knowledge, this is the first in vivo demonstration that the "effector" caspase 3 plays an "initiator" role in the regulation of caspase 9. We demonstrate next that the apoptotic function of the dsRNA-induced inhibition of protein synthesis is to potentiate the apoptotic signal downstream of, and including, the activation of caspase 8 .

\section{Materials and methods}

\section{Chemicals}

Lipofectin ${ }^{\mathrm{TM}}$ Reagent was from Invitrogen Life Technologies. Synthetic nucleic acids were from either Midland Certified Reagent Co (polyinosinic.polycytidylic acid, pI.pC; polyinosinic acid, pI; polycytidylic acid, pC), Calbiochem (pI.pC), or Pharmacia \& Upjohn (p[d(IC)]). All synthetic nucleic acids were stored at $-20^{\circ} \mathrm{C}$ as $10 \mathrm{mg} / \mathrm{ml}$ stock solution in double-distilled deionized water. All caspase inhibitors (Calbiochem) were stored at $-20^{\circ} \mathrm{C}$ as $25 \mathrm{mM}$ stock solutions in DMSO. All commonly used chemicals and cycloheximide (CHX) were from Sigma Chemical Company. CHX was dissolved freshly before use in double-distilled deionized water.

\section{Cells and plasmids}

Subconfluent cells grown on $100-\mathrm{mm}$ or $60-\mathrm{mm}$ tissue culture plates were used for experiments. HeLa and MCF-7 cells were maintained in Dulbecco modified Eagle's medium (DMEM) supplemented with $10 \%$ fetal bovine serum (HyClone) and antibiotics. Human full length caspase 3 cDNA was subcloned into a PCR3 expression vector.

\section{Lipofectin-mediated delivery of pl.pC}

Per each milliliter final volume (4/4) of Lipofectin mixture, an initial concentrated mixture (containing Lipofectin and pI.pC) was prepared in $1 / 4$ of the final volume $(250 \mu \mathrm{l})$. To this end, $10 \mu \mathrm{l}$ Lipofectin $(1 \mathrm{mg} / \mathrm{ml})$ were added to serum- and antibiotic-free DMEM, mixed, and the desired amount of pI.pC was added (in a volume of $250 \mu \mathrm{l}$ ). This mixture was left for $10 \mathrm{~min}$ at room temperature. Finally, the remaining $3 / 4$ of the final volume $(750 \mu \mathrm{l})$ of serum- and antibiotic-free DMEM were added. Before the application of the Lipofectin/pI.pC mixtures, the cells were washed once with serum- and antibiotic-free 
DMEM. The same procedure was applied for the delivery of all other synthetic nucleic acids.

\section{Preparation of cell lysates for immunoblot analysis}

To avoid potential post-lysis modifications or degradation of proteins of interest, the cells were harvested by a direct lysis in $2 \times$ DS-PAGE sample-loading buffer, followed by heat denaturation at $95^{\circ} \mathrm{C}$ for $5 \mathrm{~min}$ and a mechanical or ultrasonic shearing. Typically, the detached (dead) cells were sedimented from the growth medium by centrifugation, lysed in $2 \times$ DS-PAGE sample-loading buffer, and combined with the cell lysates from adherent cells. Cell lysates were stored at $-70^{\circ} \mathrm{C}$.

\section{Antibodies and immunoblot analyses}

The antibodies against PARP (H-250), cytochrome c (H-104), Bax (N-20, HRP-conjugated), and Bak (G-23) were from Santa Cruz Biotechnologies. The antibodies against caspase $3(65906 \mathrm{E}$; discontinued due to death of producing animal) and caspase 7 (clone B941) were from Pharmingen/BD Biosciences. The antibodies against caspase 8 (1C12) and caspase 9 (p37-specific, p35-specific, and full length/p37/p35-specific) were from Cell Signaling Technology. The antibody against Bid (rabbit, polyclonal) was from Biosource International. The Fas-activating antibody (clone $\mathrm{CH} 11$ ) was from Upstate Biotechnology. The electrophoretic separation of proteins in SDS-PAGE and electrotransfer onto PVDF membrane (Millipore) were performed using standard procedures. Immunoprobing with specific antibodies and enhanced chemiluminescent detection (DuPont NEN Research Products) were performed following the instructions of the respective manufacturers.

\section{Analysis of the subcellular distribution of Bid, Bax, Bak, and cytochrome c}

Cytosolic and organellar fractions were prepared and analyzed as previously described in ref. ${ }^{6}$ Briefly, control and treated cells were harvested by scraping directly in the medium, sedimented, washed once in ice-cold PBS and once in isotonic sucrose buffer (SU buffer: $250 \mathrm{mM}$ sucrose, $10 \mathrm{mM}$ Hepes, $10 \mathrm{mM} \mathrm{KCl}, 1.5 \mathrm{mM} \mathrm{MgCl} 2,1$ mM EDTA, 1 mM EGTA, $\mathrm{pH}$ 7.1) and then permeabilized for $1 \mathrm{~min}$ at room temperature (RT) in SU buffer containing $0.025 \%$ digitonin and Complete ${ }^{\mathrm{TM}}$ protease inhibitor cocktail. The efficiency of permeabilization was nearly $100 \%$ as measured by trypan blue exclusion. After sedimenting the cellular pellet, the supernatant was designated "cytosol(ic fraction)". The pellet of permeabilized cells was resuspended in SU buffer containing $0.5 \%$ Triton X-100 and Complete ${ }^{\mathrm{TM}}$ Protease Inhibitor Cocktail and kept for $10 \mathrm{~min}$ on ice, after which the Triton $\mathrm{X}-100$-soluble and -insoluble fractions were separated by centrifugation. All three fractions were resolved in $15 \%$ SDS-PAGE, transferred onto PVDF membrane and probed with appropriate antibodies.

\section{Infection of cells with EMCV}

Approximately $3 \times 10^{6} \mathrm{HeLa}$ cells were infected with EMCV ( $\sim 100$ pfu per cell) in $2 \mathrm{ml}$ of serum-free medium for $1 \mathrm{~h}$, after which time the excess of the virus was removed by extensive washing of the cells with serum-free medium. The cells were further incubated in serum-free medium.

\section{Results}

\section{DsRNA triggers a rapid apoptotic response in HeLa cells}

To determine the cytotoxicity of dsRNA in HeLa cells, we treated the cells with the synthetic dsRNA polyinosinic.polycytidylic acid (pI.pC, hereafter referred to as dsRNA) in the presence of Lipofectin ${ }^{\mathrm{TM}}$ reagent to ensure efficient internalization (see Experimental Procedures) and monitored, in immunoblot analyses, the cleavage (activation) of caspases 8, 9, 3, and 7 over a period of time from $1 \mathrm{~h}$ to $6 \mathrm{~h}$ post treatment. The processing of procaspase 8 was assessed employing an antibody recognizing an epitope within the large subunit of caspase 8 . Within $2 \mathrm{~h}$ post treatment, dsRNA triggered efficiently the processing of procaspase 8 to two fragments running in SDSPAGE as a doublet of $\sim 41-43 \mathrm{kDa}$ (Figure 1, panel A, lane 4). This doublet (hereafter referred to, collectively, as $\mathrm{p} 43 / \mathrm{p} 41$ ) represents the large subunit of caspase 8 with an uncleaved prodomain and it is likely to result from one of the following three reasons. First, the doublet may be the product of the utilization of two alternative cleavage sites (VETD $^{374}$ and LEMD $^{384}$ ) between the large and the small subunits. ${ }^{37}$ Second, the two fragments may be the result of the cleavage of two different splice forms of procaspase $8(\mathrm{MACH} \alpha 1 \text { and } \mathrm{MACH} \alpha 2)^{25}$ at the same cleavage site (either VETD ${ }^{374}$ or LEMD $^{384}$ ). In support of the latter notion, a better resolution of procaspase 8 in SDS-PAGE (Figure 6) demonstrates that HeLa cells express indeed two bands with procaspase 8 immunoreactivity. Finally, a combination of both expression of two splice forms of the procaspase 8 and utilization of alternative cleavage sites may explain the appearance of the doublet $\mathrm{p} 43 / \mathrm{p} 41$. With the antibody employed, neither of these three possibilities can be ruled out. Further cleavage of the p43/p41 
Figure 1. DsRNA triggers rapid apoptosis in HeLa cells. The cells were treated with Lipofectin alone (Co, control) or with Lipofectin with pl.pC (dsRNA; $3 \mu \mathrm{g} / \mathrm{ml}$ ) as described in Experimental Procedures. At the indicated times after the treatment, the cells were harvested and processed for immunoblot analyses as described in Experimental Procedures. Immunoblot detections of caspases 8 (C-8, panel A), 9 (C-9, panels B and C), $3(C-3$, panel D), and 7 (C-7, panels $E$ and $F$ ) and of PARP (panel G) were performed using appropriate antibodies as described in Results and Experimental Procedures. Here, as well as in Figure 6, the detection of p37 and p35 fragments of caspase 9 was performed using antibodies specific for the respective fragments (see Experimental Procedures). Everywhere else, procaspase 9, p37, and p35 were detected using an antibody recognizing all three polypeptides (see Experimental Procedures). See text for the description of the detected fragments of individual caspases.

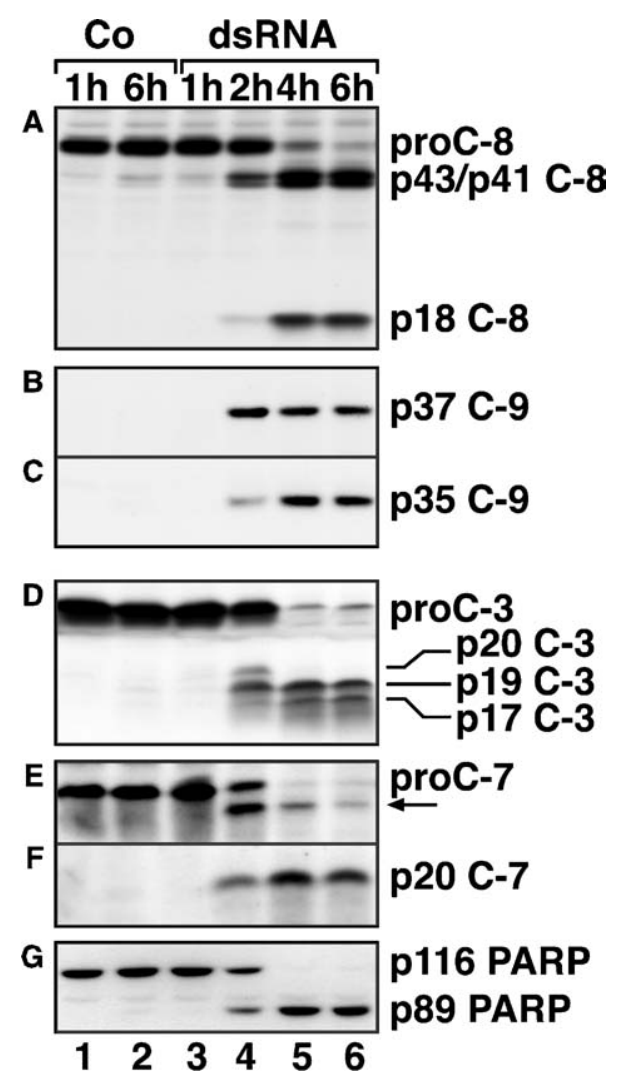

fragments of caspase 8 to the fully-processed p18 large subunit was only weakly detectable at $2 \mathrm{~h}$, but it intensified dramatically between 2 and $4 \mathrm{~h}$ after the addition of dsRNA, reaching an apparent steady-state plateau between 4 and $6 \mathrm{~h}$ post treatment (Figure 1, panel A, lanes 4-6). The small (p10) subunit of caspase 8 cannot be detected with the antibody employed. The mechanism of activation of caspase 8 by intracellular accumulation of dsRNA is addressed elsewhere (Iordanov et al., submitted).

The activation of procaspase 9 was assessed using two antibodies that discriminate between the two alternative fragments of caspase 9 resulting from different mecha- nisms of activation (see below). The cleavage of procaspase 9 at DQLD 330 to generate a $\mathrm{p} 37$ fragment [i.e. the large subunit with an uncleaved prodomain $]^{36}$ was well detectable as early as $2 \mathrm{~h}$ post treatment with dsRNA and the steady-state levels of p37 did not intensify detectably between 2 and $6 \mathrm{~h}$ (Figure 1, panel B, lanes 4-6). In contrast, the appearance of $\mathrm{p} 35$ fragment of caspase 9 [cleavage at PEPD $\left.^{315}\right]^{36}$ was delayed and reached stable steady-state levels between 2 and $4 \mathrm{~h}$ post treatment (Figure 1, panel C, lanes 4-6). Thus, the time course of appearance of the p37 and $\mathrm{p} 35$ fragments of caspase 9 provided support to the notion that during the response of HeLa cells to dsRNA procaspase 9 is activated first via cleavage by the effector caspase 3 at DQLD 33036 and later via autocatalytic processing at PEPD ${ }^{315} .{ }^{36}$ Consistent with the findings of Srinivasula et al. ${ }^{36}$ the prodomain of caspase 9 was not proteolytically removed from the p37 and p35 fragments (see Figure 8). Procaspase 3 was processed in response to dsRNA first by the cleavage of the procaspase at IETD ${ }^{175}$ to form a short-lived intermediate p20 (large subinit with an uncleaved prodomain ${ }^{37,49,50}$ ) detectable only at $2 \mathrm{~h}$ post dsRNA (Figure 1, panel D, lane 4). The p20 fragment was further processed to produce two forms of the large subunit, $\mathrm{p} 19$ and $\mathrm{p} 17$, resulting from the successive (auto)cleavages at NSVD ${ }^{9}$ and ESMD ${ }^{28}$ 37,49,50 (Figure 1, panel D, lanes 4-6). Procaspase 7 was processed through a proteolytic intermediate of unclear identity (Figure 1, panels $\mathrm{E}$ and $\mathrm{F}$, lanes 4-6, arrow) that matured, eventually, to the p20 large subunit. To monitor the overall degree of apoptosis in the dsRNA-treated HeLa cells, we assessed the proteolytic cleavage of PARP. Strikingly, the cleavage of PARP was completed between 2 and $4 \mathrm{~h}$ after the treatment with dsRNA (Figure 1, panel G, lanes 4-6), suggesting that a complete course of apoptosis can be executed within $4 \mathrm{~h}$ of the treatment of HeLa cells with dsRNA.

In order to determine whether the results shown in Figure 1 were due indeed to the double-stranded RNA nature of the introduced pI.pC, we performed identical experiments with the exception that instead of pI.pC, we employed ssRNA (either $\mathrm{pI}$ or $\mathrm{pC}$ ) as well as dsDNA (p[d(IC)]). Neither ssRNA nor dsDNA displayed any detectable toxicity for up to $48 \mathrm{~h}$, after which time the experiment was terminated (not shown). We concluded, therefore, that dsRNA (but not ssRNA or dsDNA) is exclusively capable of triggering rapid apoptosis in HeLa cells.

\section{A prominent role for caspase 8 in the initiation of the rapid dsRNA-induced apoptosis}

To elucidate the order of caspase activation in dsRNAinduced apoptosis, we employed general or specific inhibitors of caspase activities: zVADfmk, a pan-caspase 
inhibitor, zDEVDfmk, an inhibitor of effector caspases (DEVDases, such as caspases 3 and 7), zIETDfmk, an inhibitor of caspase 8, and zLEHDfmk, an inhibitor of caspase 9. ${ }^{51,52} \mathrm{HeLa}$ cells were treated with dsRNA for 2 or $4 \mathrm{~h}$ in the absence or in the presence of a $30 \mathrm{~min}$ pretreatment with the respective caspase inhibitor (50 $\mu \mathrm{M}$ each) and the proteolytic processing of the initiator caspases 8 and 9, and of the effector caspases 3 and 7 was monitored in immunoblot analyses. The overall effect of caspase inhibition by each inhibitor was determined by the degree of cleavage of PARP. The outcome of these analyses is presented in Figure 2. The pancaspase inhibitor zVADfmk potently inhibited the activation by dsRNA of all caspases studied and prevented almost completely the processing of PARP (Figure $2 \mathrm{~A}$, compare lanes 4 and 10 to lanes 5 and 11). At the concentration used, the caspase 8 inhibitor zIETDfmk strongly inhibited and delayed (but did not completely abolish) the first step on processing of procaspase 8 , namely the autocatalytic cleavage at VETD ${ }^{374}\left(\right.$ and/or LEMD $\left.{ }^{384}\right)$ to produce the p43/p41 fragments (Figure 2A, compare lanes 4 and 10 to lanes 6 and 12). Interestingly, zIETDfmk was almost as efficient in inhibiting the dsRNA-induced processing of procaspase 9 (shown in Figure 2A, lanes 4 and 10) as the pancaspase inhibitor zVADfmk (Figure 2A, compare lanes 5 and 11 to lanes 6 and 12). This result, together with the temporal sequence of appearance of the two caspase 9 fragments (i.e., the appearance of the caspase 3 -processed p37 first and of the caspase 9-processed p35 second; Figure 2A, compare lanes 4 and 16 to lanes 10 and $22)$, strongly supports the notion that caspase 8 -activated caspase 3 is instrumental the activation of caspase 9 in response to dsRNA. zIETDfmk suppressed (2 h, Figure 2A, compare lanes 4 and 6) and delayed ( 4 h, Figure 2A, compare lanes 10 and 12) the processing of procaspase 3 . Thus, at $4 \mathrm{~h}$, the processing of caspase 3 was arrested by zIETDfmk at the level of the p20 intermediate fragment (Figure 2A, compare lanes 10 and 12). zIETDfmk affected the dsRNA-induced processing of procaspase 7 similarly to its effects on procaspase 3 (Figure 2A). Finally, zIETDfmk substantially delayed, but did not prevent the processing of PARP (Figure 2A, compare lanes 4 and 10 to lanes 6 and 12). As expected, the caspase 9 inhibitor zLEHDfmk strongly suppressed the appearance of the autocatalytically-produced p 35 fragment, but was much less effective in suppressing the processing of procaspase 9 to the p37 fragment by caspase 3 (Figure 2B, compare lanes 16 and 22 to lanes 18 and 24). Similar to zIETDfmk, but significantly less efficiently, zLEHDfmk appeared to inhibit the last step of the processing of procaspase 3, namely, the conversion of p20 to the p19 and p17 fragments (Figure 2B, compare lanes 16 and 22 to lanes 18 and 24). Consistent with the inefficient ability of zLEHDfmk to block the processing of caspase 3, the inhibitor was also inefficient in blocking the cleav-
Figure 2. Inhibition of dsRNA-induced apoptosis by caspasespecific peptide inhibitors. (A) and (B) HeLa cells were treated, for the indicated times, as in Figure 1, except for the $30 \mathrm{~min}$ pre-incubation of the cells, where indicated, with various caspase inhibitors. Immunoblot detections of caspases $8,9,3$, and 7 and of PARP are presented. See text for the description of the detected fragments of individual caspases. "-", no pretreatment with inhibitors or treatment with dsRNA; VAD, zVADfmk; IETD, zIETDfmk; DEVD, zDEVDfmk; LEHD, zLEHDfmk.

A

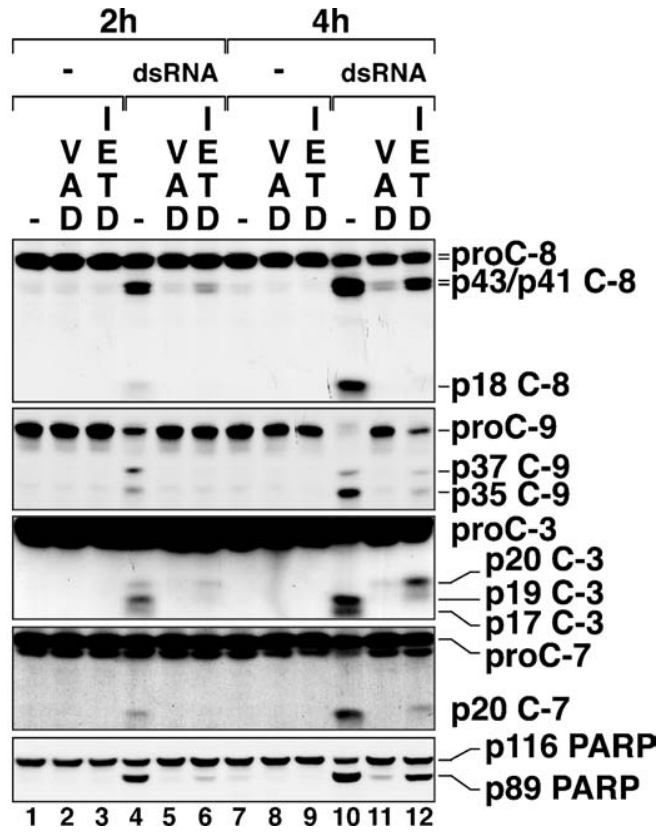

B

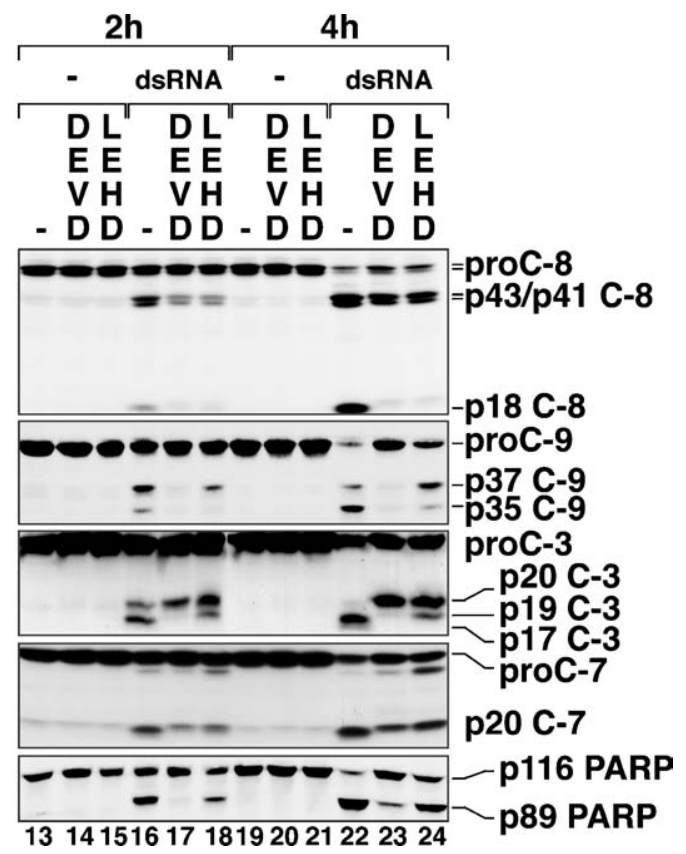

age of PARP (Figure 2B, compare lanes 16 and 22 to lanes 18 and 24). The inhibitor of "DEVDases" (caspases 3 and 7) zDEVDfmk displayed an equal to zVADfmk ability to block the processing of procaspase 9 at both 
the DQLD ${ }^{330}$ site (p37 fragment) and the PEPD ${ }^{315}$ site (p35 fragment) (Figure 2, compare lanes 4, 5, 10, 11, $16,17,22$, and 23). The specificity of this inhibitor is demonstrated by the fact that, at the level of processing of procaspase 3, zDEVDfmk blocked the autocatalytic processing of p20 to p19/p17, but failed completely to inhibit the formation of p20 in the first place (Figure 2B, compare lanes 16 and 22 to lanes 17 and 23). Consistent with the inhibition of DEVDases by zDEVDfmk, the dsRNA-induced proteolytic cleavage of PARP was strongly suppressed by zDEVDfmk (Figure 2B, compare lanes 16 and 22 to lanes 17 and 23). Interestingly, all four caspase inhibitors used proved equally efficient in blocking the final processing of the $\mathrm{p} 43 / \mathrm{p} 41$ fragments of caspase 8 to the mature p18 large subunit (Figure 2, compare lanes 4 and 10 to lanes 5, 6, 11, 12, 17, 18, 23, 24).

\section{The dsRNA-induced processing of procaspase 9 to $\mathrm{p} 37$ (but not to $\mathrm{p} 35$ ) requires caspase 3}

To determine whether the dsRNA-induced cleavage of procaspase 9 at DQLD ${ }^{330}$ is mediated exclusively by caspase 3 (or, alternatively, could be executed by another DEVDase, such as caspase 7), we employed the human breast carcinoma cell line MCF-7, which has been previously reported to lack detectable levels of caspase 3 protein. ${ }^{53} \mathrm{We}$ confirmed that MCF-7 cells express detectable levels of caspase 7, but are indeed devoid of caspase 3 (Figure 3A, panels A3 and A4). When challenged with dsRNA, MCF7 cells demonstrated a processing of procaspase 8 that was identical (albeit delayed) in the nature of the detected fragments to the processing of caspase 8 in dsRNA-treated HeLa cells (Figure 3A, panel A1, lanes 5-8). However, only the p35, but not the p37, fragment of caspase 9 was detectable in the dsRNA-treated MCF-7 cells (Figure $3 \mathrm{~A}$, panel A2, lanes 5-8). The transient overexpression of full length caspase 3 in MCF-7 cells proved to be cytotoxic and precluded the possibility of studying the effects of restoring caspase 3 expression on the dsRNAinduced apoptosis. However, upon transfection of caspase 3 in MCF-7 cells (Figure 3B, panel B1, lanes 3 and 4), a clear increase in the appearance of $\mathrm{p} 37$ fragment of caspase 9 was observed (Figure 3B, panel B3, lanes 3 and 4), consistent with the notion that caspase 3 is indeed capable of cleaving procaspase 9 at DQLD ${ }^{330}$. The fact that some constitutive appearance of the p 37 fragment of caspase 9 was observed in the absence of transfected caspase 3 (Figure $3 \mathrm{~B}$, panel $\mathrm{B} 3$, lanes 1 and 2) suggests that caspase 3 is not the only caspase capable of cleaving the DQLD ${ }^{330}$ site of caspase 9. Taken together, the results presented in Figure $3 \mathrm{~A}$ and $\mathrm{B}$ strongly support the notion that caspase 3 is a major DEVDase responsible for the processing of caspase 9 at the DQLD ${ }^{330}$ cleavage site.
Figure 3. Absence of detectable levels of caspase 3 and reduced p37 caspase 9 fragment in MCF-7 cells. (A) MCF-7 cells were treated as HeLa cells were in Figure 1. Immunoblot detections of caspases 8 (C-8, panel A1), 9 (C-9, panel A2), 3 (C-3, panel A3), and 7 (C-7, panel A4) and of PARP (panel A5) are presented. See text for the description of the detected fragments of individual caspases. (B) MCF-7 cells were transfected in duplicates with either an empty PCR3 expression vector (lanes 1 and 2) or PCR3caspase 3 construct. Twenty for hour later the cells were harvested and processed for immunoblot analyses of caspase 3 (panel B1), procaspase 9 (panel B2), p37 caspase 9 (panel B3), and p35 caspase 9 (panel B4).

A

MCF-7

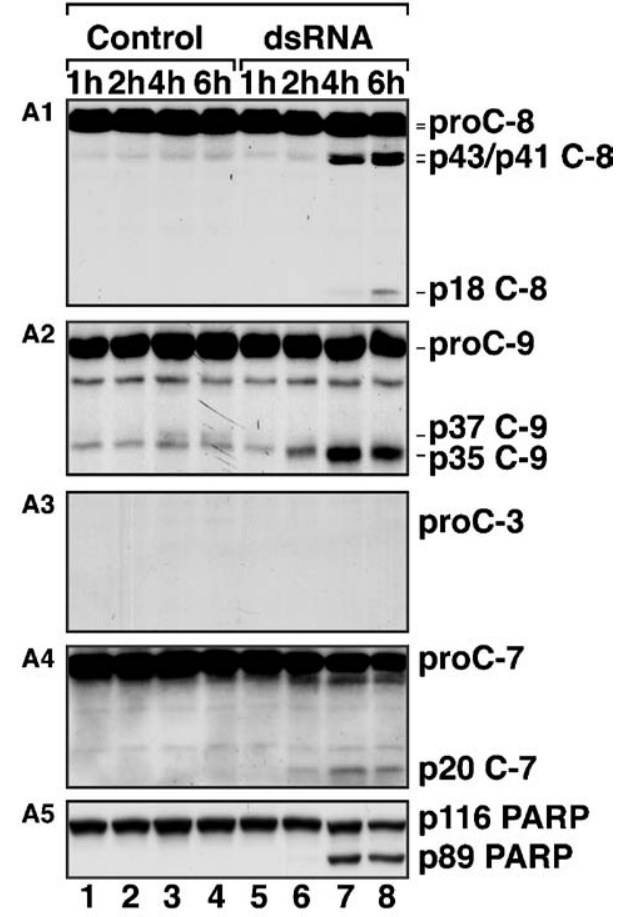

B

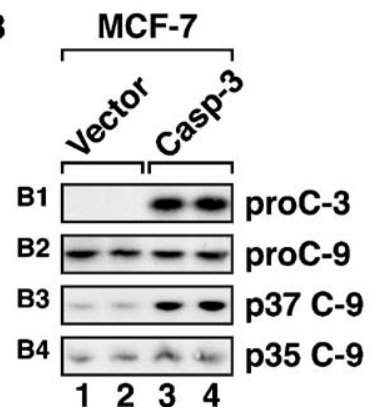

Mobilization of Bid, Bax, and Bak, and release of cytochrome $\mathrm{c}$ from mitochondria in response to dsRNA

To determine the mechanism of activation of caspase 9 in dsRNA-treated HeLa cells, we investigated the status of Bid, Bax, Bak, and cytochrome c in dsRNA-treated HeLa cells. To this end, we fractionated cells into 3 fractions: (i) a cytosolic fraction containing soluble proteins 
Figure 4. Mobilization of Bid, Bax, and Bak, and release of cytochrome $c$ from mitochondria in response to dsRNA. (A and $B$ ) Where indicated, HeLa cells were treated for $3 \mathrm{~h}(\mathrm{~A})$ or $6 \mathrm{~h}$ (B) with $\mathrm{CHX}(25 \mu \mathrm{g} / \mathrm{ml}), \mathrm{CH} 11(0.5 \mu \mathrm{g} / \mathrm{ml}), \mathrm{dsRNA}(\mathrm{pl} . \mathrm{pC} ; 3 \mu \mathrm{g} / \mathrm{ml})$, or the indicated combinations thereof. The cells were processed as described in Experimental Procedures to yield three fractions as follows: cytosol (lanes 1, 4, 7, 10, 13, and 16), non-cytosolic (organellar) material soluble in Triton X-100 ["S" (supernatant), lanes 2, 5, 8, 11, 14, and 17], and non-cytosolic (organellar) material resistant to solubilization in Triton X-100 ["P" (pellet), lanes 3, 6, 9, 12, 15, 18). Immunoblot analyses depicting the appearance of Bid, Bax, Bak, and cytochrome c, in each fraction are presented. The membranes were re-probed for caspase 8 and PARP to monitor for the overall degree of apoptosis after each treatment. Results are interpreted in the text.

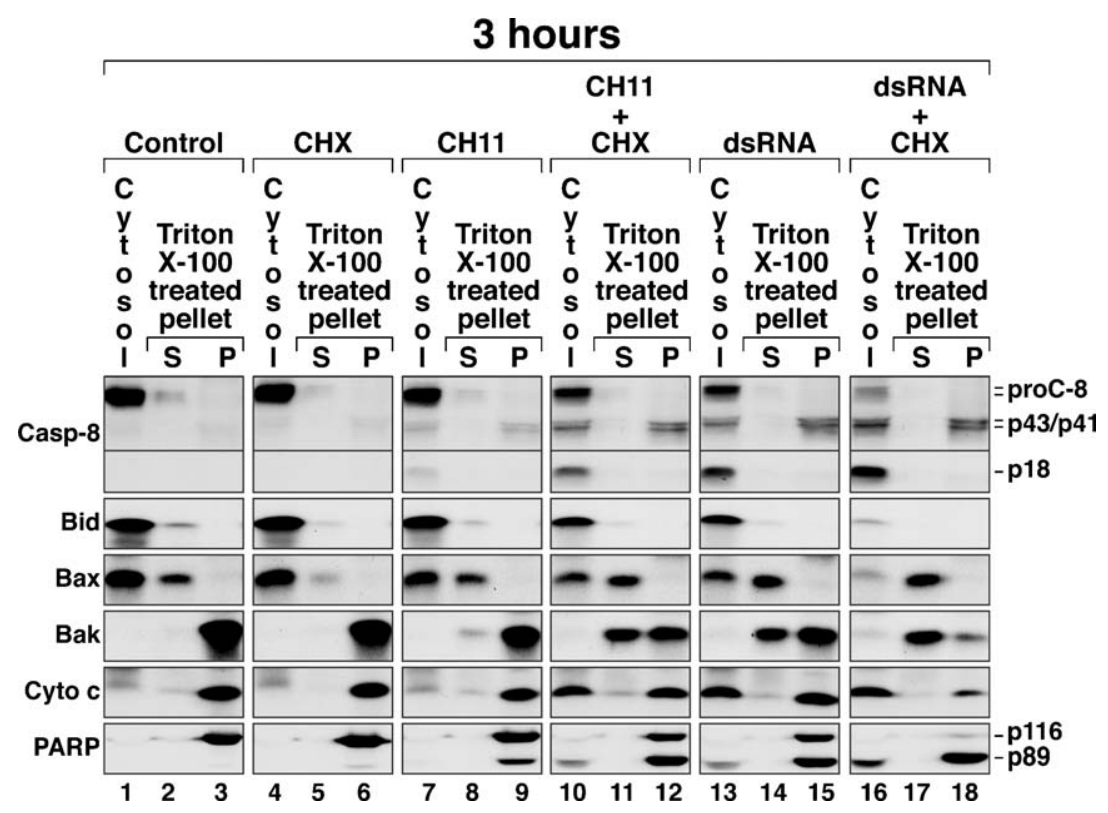

(A)

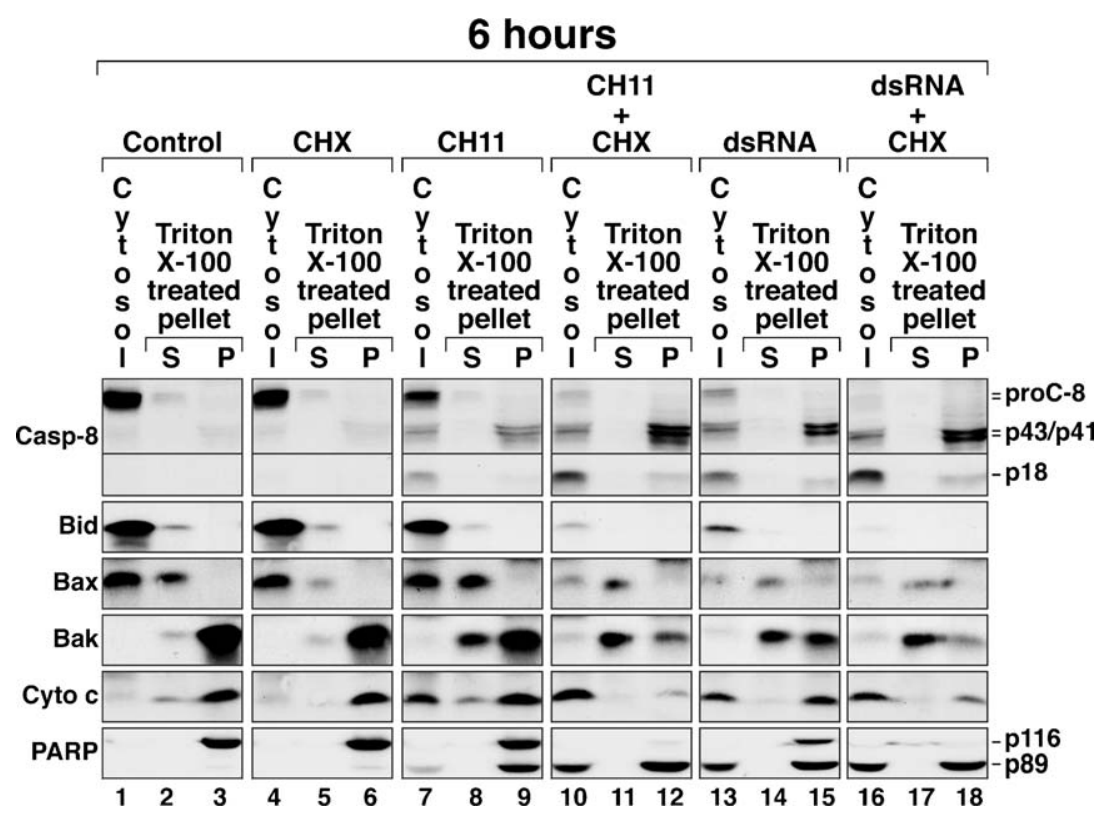

(B)

(represented in Figure 4 by lanes 1, 4, 7, 10, 13, and 16), (ii) a fraction containing proteins that are associated with organellar, nuclear, or plasma membranes but are solubilized in Triton X-100 (represented in Figure 4 by lanes $2,5,8,11,14$, and 17), and (iii) a fraction of intraorganellar proteins that are resistant to solubilization with Triton X-100 (represented in Figure 4 by lanes 3, 6, 9, 12, 15, and 18; see Experimental Procedures). In untreated cells, cytochrome $\mathrm{c}$ was sequestered exclusively in mitochondria (Figures $4 \mathrm{~A}, \mathrm{~B}$, and 5, lane 
3). Consistent with the essential role of cytochrome $c$ in the autocatalytic cleavage of caspase 9 to produce the p35 fragment, in dsRNA-treated HeLa cells there was a detectable release of cytochrome c from mitochondria into the cytosol (Figure 4, compare lanes 1 and 13). Bax and Bak exert redundant roles in mediating cytochrome c release in apoptosis. ${ }^{41}$ As expected, ${ }^{43-46}$ in untreated cells, we observed Bak exclusively in the Triton X-100-resistant fraction (Figure 4, lane 3). Following dsRNA treatment, a redistribution of Bak toward the Triton X-100-soluble fraction was detected (Figure 4, compare lanes 2 and 14). At the same time, Bax, which is a mainly cytosolic protein $\left[^{45}\right.$ and see (Figures $4 \mathrm{~A}, \mathrm{~B}$, and 5, lane 1)] displayed, in response to dsRNA treatment, a tendency toward increased association with the surface of mitochondria ${ }^{42}$ at $3 \mathrm{~h}$ post treatment with dsRNA (Figure 4A, compare lanes 1, 2, 13, and 14), followed by an apparent degradation at $6 \mathrm{~h}$ post treatment (Figure 4B, compare lanes 1, 2, 13, and 14). Finally, we investigated the effects of dsRNA on the caspase 8 substrate Bid. The full size Bid protein displayed cytosolic distribution in untreated cells (Figure 4, lane 1). In response to dsRNA, the steady-state levels of full size Bid declined in a time-dependent fashion, (Figure 4, compare lanes 1 and 13). With the antibody available, we were unable to detect the p15 truncated fragment of $\mathrm{Bid}(\mathrm{tBid})$ that results from the cleavage of the full size protein by caspase 8 and that translocates to the surface of mitochondria. ${ }^{39,40}$ However, the disappearance of full size Bid from the dsRNA-treated cells was unlikely to result from the mere dsRNA-induced inhibition of protein synthesis and high turnover rate of the protein, since $\mathrm{CHX}$, a potent protein synthesis inhibitor, failed to trigger any detectable changes in Bid levels even at $6 \mathrm{~h}$ post addition (Figure 4B, lane 4). We concluded, therefore, that following the activation of caspase 8 in dsRNAtreated HeLa cells, the pro-apoptotic Bcl-2 family members Bid, Bax, and Bak are mobilized to trigger the release of cytochrome $\mathrm{c}$ from mitochondria, thus providing the potential mechanism for the autocatalytic processing of caspase 9 .

\section{A role for the inhibition of protein synthesis in accelerating the execution of apoptosis downstream of, and including, the activation of caspase 8}

Does the dsRNA-induced inhibition of protein synthesis play a role in the rapid dsRNA-induced apoptosis? We have previously demonstrated that inhibition of protein synthesis by inhibitors of translation triggers, on its own, apoptotic cell death in HeLa cells. ${ }^{6}$ This apoptotic response, however proceeds with significantly delayed kinetics compared to the cell death triggered by dsRNA (Figure 1 and ref. ${ }^{6}$; therefore, we consider it highly unlikely that inhibition of translation alone could account for the rapid apoptosis triggered by dsRNA. We speculated, however, that the inhibition of protein synthesis might play a role in accelerating the execution of apoptosis triggered by the activation of an apical caspase (such as caspases 8 or 9). To test this possibility, we activated caspase 8 with $\mathrm{CH} 11$ (a Fas-activating antibody that does not, on its own, cause a significant inhibition of $\left[{ }^{3} \mathrm{H}\right]$-leucine incorpopration in HeLa cells; not shown) in the absence or in the presence of $\mathrm{CHX}$. $\mathrm{CHX}$ alone was inefficient in triggering any of apoptotic steps we have investigated (e.g., activation of caspase 8 , mobilization of $\mathrm{Bid}, \mathrm{Bax}$, and $\mathrm{Bak}$, release of cytochrome c, or cleavage of PARP) for up to $6 \mathrm{~h}$ post addition (Figure 4, lanes 4-6). The $\mathrm{CH} 11$-treated cells displayed little activation of caspase 8 , mobilization of $\mathrm{Bid}, \mathrm{Bax}$, and Bak, and release of cytochrome $\mathrm{c}$ at $3 \mathrm{~h}$ post addition (Figure 4A, lanes 7-9), but displayed a detectable activation of these apoptotic pathways at $6 \mathrm{j}$ post addition (Figure 4B, lanes 7-9). However, both 3 and $6 \mathrm{~h}$ following the combined treatment of cells with both $\mathrm{CH} 11$ and $\mathrm{CHX}$, a dramatic acceleration of the activation of caspase 8 was observed (Figure 4, lanes 1012). Subsequently, CHX increased the $\mathrm{CH} 11$-induced mobilization of Bid, Bax, and Bak, the release of cytochrome $\mathrm{c}$, and the cleavage of PARP (Figure 4, compare lanes 7-9 to lanes 10-12). Overall, the apoptotic potential of $\mathrm{CH} 11$ in the presence of $\mathrm{CHX}$ was indistinguishable from the one displayed by dsRNA alone (Figure 4, compare lanes 10-12 to lanes 13-15). CHX was able to accelerate the dsRNA-induced apoptosis as well, but to a much lesser degree than the effect of $\mathrm{CHX}$ on the $\mathrm{CH} 11$-induced apoptosis (Figure 4, compare lanes 13-15 to lanes 16-18), suggesting that CHX accelerates a process that dsRNA alone is capable of initiating through the dsRNA-induced inhibition of protein synthesis.

Surprisingly, we discovered that the acceleration of apoptosis caused by inhibition of protein synthesis is not invariably operational, but rather depends on the nature of the specific apoptotic stimulus. To this end, we investigated the degree to which $\mathrm{CHX}$ affected the cell death triggered by ultraviolet-B (UVB) radiation. We observed that, within $6 \mathrm{~h}$ post treatment, UVB triggered typical apoptotic features in HeLa cells, including the processing of caspase 8 to $\mathrm{p} 43 / \mathrm{p} 41$ (but not to $\mathrm{p} 18$ ), translocations of Bax and Bak, release of cytochrome c, and cleavage of PARP (Figure 5, lanes 4-6). However, the presence of $\mathrm{CHX}$ failed to accelerate, specifically, the processing of caspase 8 to p18 and, in general, the overall progression of apoptosis (Figure 5, compare lanes 4-6 to lanes 7-9). 
Figure 5. Mobilization of Bid, Bax, and Bak, and release of cytochrome $\mathrm{c}$ from mitochondria in response to UV-B. Where indicated, HeLa cells were treated for $6 \mathrm{~h}$ with UV-B $\left[2400 \mathrm{~J} / \mathrm{m}^{2}\right.$; the mode of UV-B irradiation has been described previously in refs $^{72,73}$ ] or a combination of UV-B and CHX $(25 \mu \mathrm{g} / \mathrm{ml})$. The cells were processed and each fraction was designated as in Figure 4. Immunoblot analyses depicting the appearance of Bid, Bax, Bak, and cytochrome c in each fraction, are presented. The membranes were re-probed for caspase 8 and PARP to monitor for the overall degree of apoptosis after each treatment. Results are interpreted in the text.

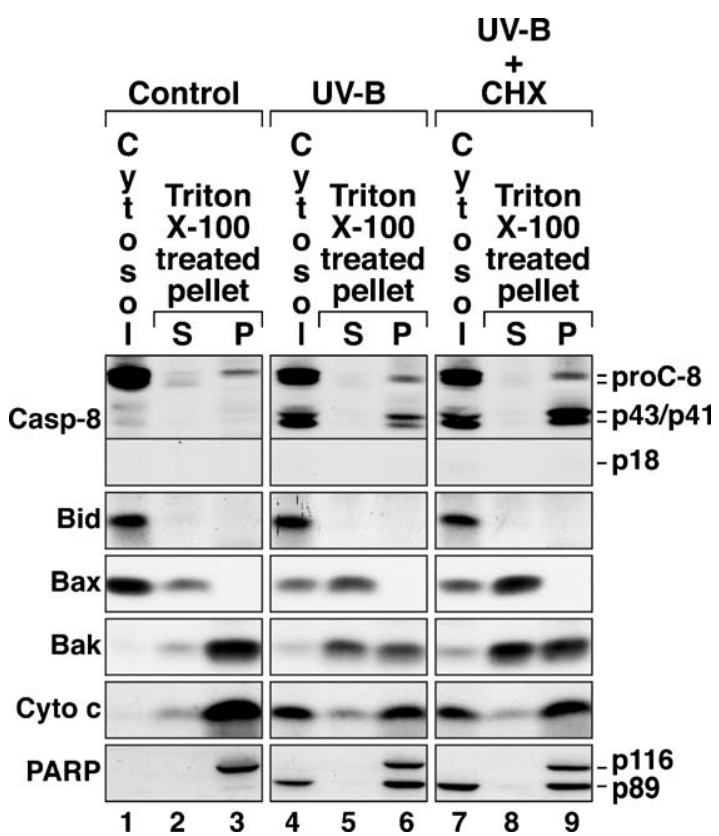

Recapitulation of the dsRNA-triggered apoptotic pathways by infection with encephalomyocarditis virus (EMCV)

We investigated the appearance of apoptosis after a bona fide infection with virus. Both at 8 and at $20 \mathrm{~h}$ after the infection of HeLa cells with EMCV, we observed processing of caspases $8,9,3,7$, and appearance of DEVDase activity, as assessed by the cleavage of PARP (Figure 6). Translocations of Bax and Bak, and release of cytochrome $\mathrm{c}$ from mitochondria were also detected (not shown). In conclusion, the apoptotic features displayed by HeLa cells after either introduction of synthetic dsRNA or infection with EMCV were identical, with the exception that EMCV-induced apoptotic phenotype required longer times to develop than the dsRNA-induced apoptosis. This finding is consistent with the longer times required for the accumulation of viral dsRNA after infection compared to the rapid accumulation of intracellular synthetic dsRNA introduced via lipofection.
Figure 6. Apoptosis triggered by EMCV infection. HeLa cells were infected, where indicated, with EMCV as described in Experimental Procedures. At the indicated times ( $h$, hours), the cells were harvested, processed for immunoblot analyses, and analyzed as in Figure 1.

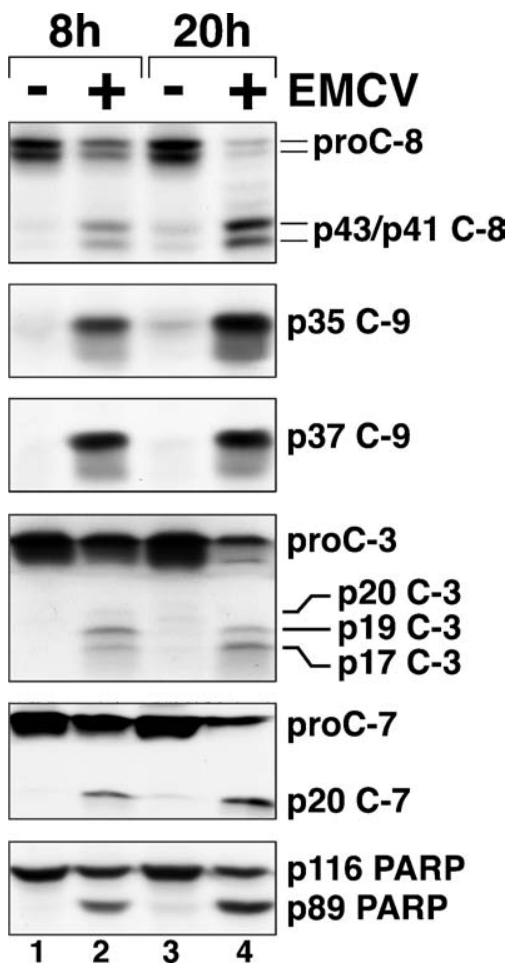

\section{Discussion}

Key role of caspase 8 in initiating dsRNA-induced apoptosis

Using kinetic analysis (Figure 1) and specific peptide inhibitors of caspases (Figure 2) we have identified caspase 8 as a key initiator of dsRNA-induced apoptosis in $\mathrm{HeLa}$ cells. Our findings are in agreement with those of Balachandran $e t$ al. who have previously reported the activation of caspase 8 in dsRNA-treated mouse fibroblasts. ${ }^{5}$ The direct activation of caspase 3 by caspase 8 is supported by the cleavage of caspase 3 at a consensus caspase 8 cleavage sequence (IETD ${ }^{175}$ ) in the procaspase 3 molecule and by the ability of zIETDfmk to suppress efficiently the dsRNA-induced processing of procaspase 3 to p20 and, subsequently, to p19/p17 (Figure 2A). The indirect activation of effector caspases by caspase 8 via a mitochondriadependent pathway appears to involve the translocation of Bid, Bax, Bak, and cytochrome c (Figure 4), presumably leading to the activation of caspase 9 . We cannot rule out the possibility that a signaling event that does not involve caspase 8 and Bid cleavage may trigger the release of cytochrome $\mathrm{c}$ from mitochondria and contribute to the overall activation of caspase 9. However, the substantial 
Figure 7. A model for the apoptotic action of viral dsRNA. The major dsRNA-activated apoptosis signaling pathways identified in this work are depicted. OAS, $2^{\prime}-5^{\prime}$ oligoadenylate synthase.

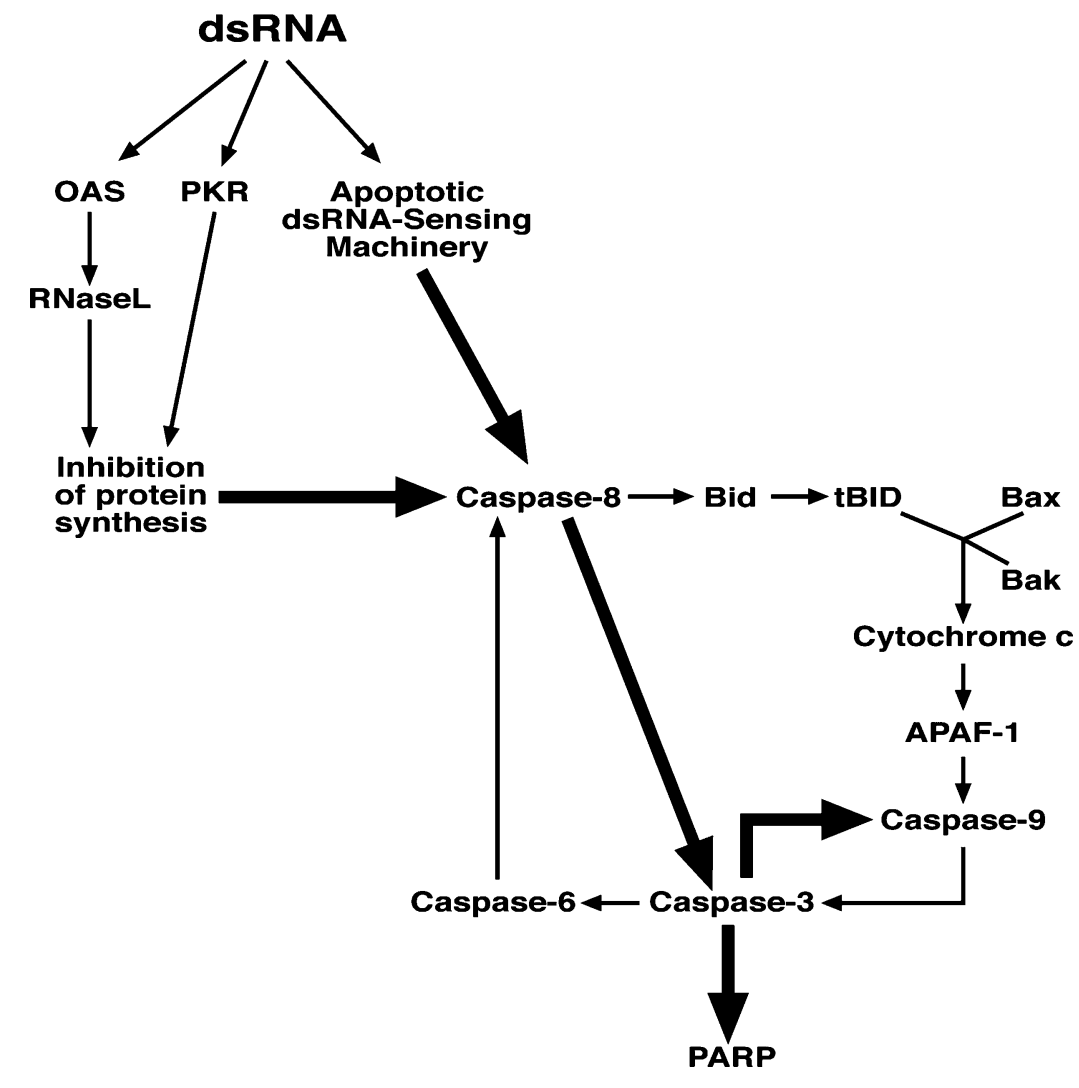

inhibition of the dsRNA-induced activation of caspase 9 in the presence of the caspase 8 inhibitor zIETDfmk (Figure 2A) suggests that the major pathway contributing to the bulk of active caspase 9 is dependent on activation of caspase 8 (Figure 7).

\section{An alternative pathway for the activation of caspase 9}

The "classical" pathway of cytochrome c-dependent autocatalytic activation of procaspase 9 results from the autocleavage at PEPD ${ }^{315}$ to produce a p35 fragment. ${ }^{36}$ We have identified in dsRNA-treated (or EMCV-infected) HeLa cells an alternative pathway to the activation of caspase 9 that appears to precede the cleavage at PEPD ${ }^{315}$. This pathway involves the caspase 3-mediated processing of procaspase 9 at DQLD 330 to yield a p37 fragment of caspase 9 (Figures 1, 2, and 6).

The experimental evidence supports the notion that the $\mathrm{p} 37$ fragment of caspase 9 is produced exclusively by the DEVDase caspase 3. First, the dsRNA-induced processing of caspase 9 is blocked by the DEVDase inhibitor zDEVDfmk. Second, dsRNA was unable to trigger the appearance of $\mathrm{p} 37$ in MCF7 cells (that lack caspase 3 but contain caspase 7; Figure 3). According to the model pro- posed by Srinivasula et al., ${ }^{54}$ the BIR 3 region of XIAP binds to the $\mathrm{N}$-terminus of the small subunit of caspase 9, thereby inhibiting it. However, the binding of (and inhibition by) XIAP occurs only if the N-terminal ATPF motif of the small subunit has been exposed by the autocleavage at PEPD ${ }^{315}$. Srinivasula et al. have found that XIAP cannot not bind (and cannot inhibit) the uncleaved zymogen, procaspase $9 .{ }^{54}$ We suggest that the cleavage of procaspase 9 at $\mathrm{DQLD}^{330}$ may create an alternative version of the small subunit of caspase 9 that lacks an exposed N-terminal ATPF motif, which now remains as part of the large p37 subunit. This alternative version of the processed procaspase 9 may be resistant to inhibition by XIAP and perhaps other BIR3-containing IAPs. Further experiments are necessary to test this hypothesis and to determine if cells that display this alternative form of caspase 9 cleavage display also an increased sensitivity to the pro-apoptotic effects of dsRNA.

\section{The role of dsRNA-induced inhibition of protein synthesis in the cytotoxicity of dsRNA}

The best-characterized effect of dsRNA on cells is the inhibition of protein synthesis. In response to dsRNA, $\mathrm{PKR}^{55}$ phosphorylates the $\alpha$-subunit of the eukaryotic 
Figure 8. Proposed sequence of caspase-activating events during dsRNA-induced apoptosis in HeLa cells. Four major steps are identified (1)-(4). (1). In the first step, procaspase 8 undergoes an autocatalytic processing and activation by proteolysis at VETD and/or LEMD motifs between the large and the small subunits. This step is strongly suppressed by zVADfmk (pan-caspase inhibitor) and zIETDfmk (caspase 8 inhibitor), and to a significantly lesser extent by zLEHDfmk (caspase 9 inhibitor) or zDEVDfmk (DEVDase inhibitor). The further processing of caspase 8 to remove the prodomain is delayed, inefficient (Figure 1), and inhibited by all caspase inhibitors used (Figure 4). The inefficient processing of the prodomain is likely to result from the strongly non-consensus nature of the available cleavage sites [TISD and REQD ${ }^{51}$ ]. (2). In the second step, procaspase 3 is processed by caspase 8 (inhibition by zIETDfmk, Figure 4A) at the IETD sequence between the large and the small subunits. Further cleavage involves the autocatalytic (inhibited by zDEVDfmk) generation of $\mathrm{p} 19$ and p17 (presumably via cleavages at NSVD and ESMD). (3). In the third step, procaspase 9 is processed by caspase 3 to the p37 (prodomain + large subunit) and the p10 small subunit at DQLD. (4). In the fourth step, p37 (and/or procaspase 9 ) is further processed to p35 by an autocatalytic cleavage at PEPD. The RPVD sequence located between the prodomain and the large subunit of caspase 9 should be prohibitive for cleavage due to the presence of an arginine residue at P4 position. ${ }^{51}$ This is the likely reason for the lack of observable prodomain cleavage in the case of caspase $9{ }^{36}$ and this work]. For all steps, ProD indicates the prodomain of a respective (pro)caspase. Arrowheads indicate cleavage and blunted lines indicate inhibition of a cleavage by a respective inhibitor.

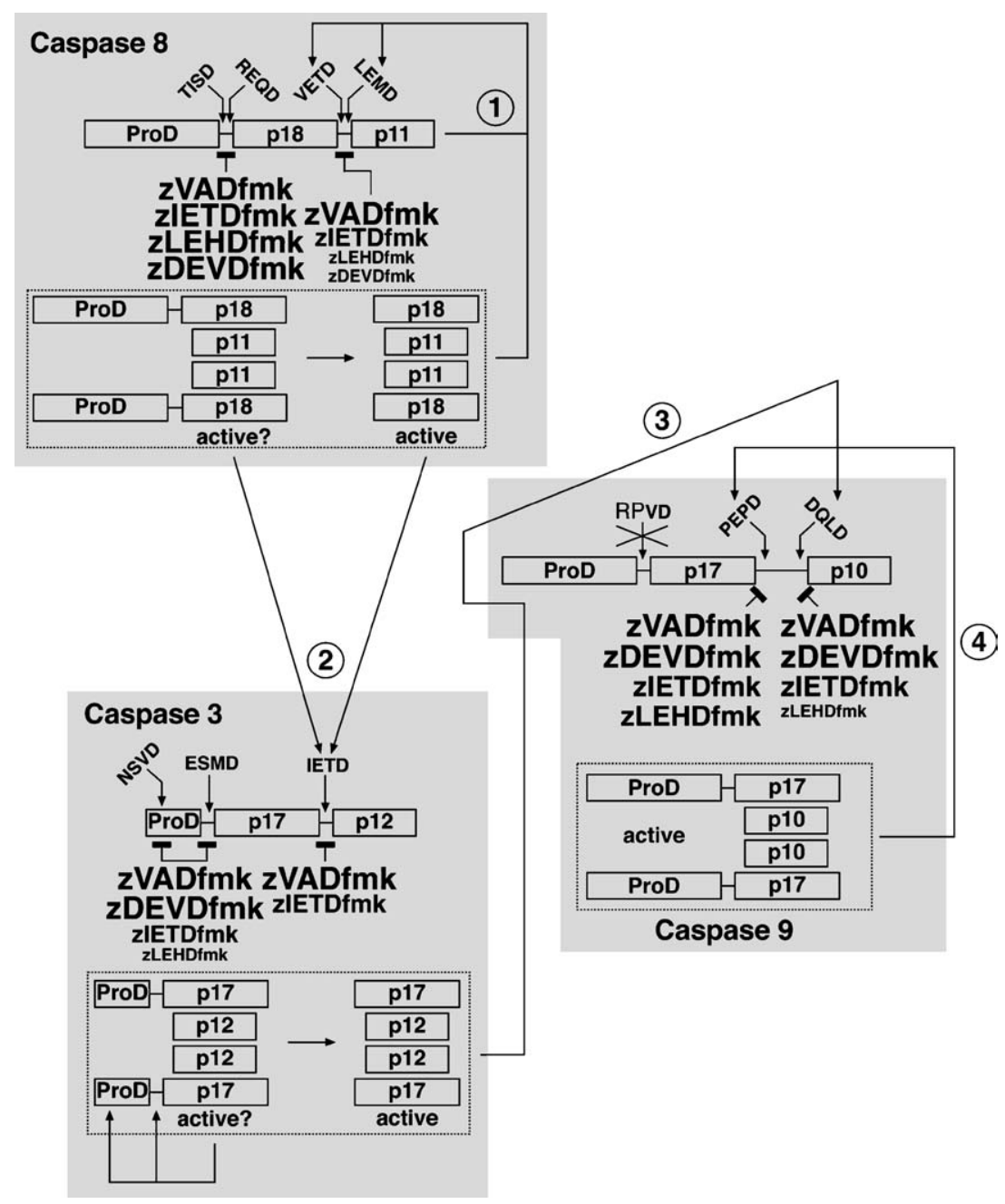

translation initiation factor $2(\mathrm{eIF}-2 \alpha),{ }^{56}$ thereby greatly reducing the initiation of translation. ${ }^{57}$ The $2^{\prime}-5^{\prime}$ oligoadenylate synthase/RNase $\mathrm{L}$ system is composed of a family of dsRNA-dependent enzymes known as $2^{\prime}-5^{\prime}$ oligoadenylate synthases ${ }^{58}$ and the dormant cytosolic ribonuclease L (RNase L). ${ }^{59} 2^{\prime}-5^{\prime}$ oligoadenylate-activated RNase L cleaves diverse RNA substrates, including $18 \mathrm{~S}$ and $28 \mathrm{~S}$ rRNA, thereby inhibiting cellular protein synthesis. 3,60,61 We have previously shown that fibroblasts from mice nullizygous for both PKR and RNase L alleles are unable to inhibit protein synthesis when challenged with dsRNA, ${ }^{3}$ thereby demonstrating that these two enzymes are both required and sufficient for the translational inhibition caused by dsRNA.

Both PKR $5,9,48,62-65$ and RNase $\mathrm{L}^{66-70}$ have been implicated in mediating virus-induced apoptosis. 
Considering the role of both PKR and RNase L in inhibiting protein synthesis, one obvious candidate for a PKRand/or RNase L-induced death signal is the impaired process of translation. Although the inhibition of protein synthesis can ultimately lead to the apoptotic death of cells, ${ }^{6}$ perhaps in part by preventing the synthesis of short-lived pro-survival molecules, the results presented in Figure 4B demonstrate that the mere inhibition of protein synthesis is clearly unable to account for the rapid dsRNA-induced apoptosis. For example, cycloheximide was unable to trigger the activation of caspase 8 in HeLa cells for up to $6 \mathrm{~h}$, despite the complete inhibition of translation. The results presented in Figure 4 have shown that the Fas- or dsRNA-induced activation of caspase 8 was accelerated by the inclusion of CHX in the medium. The steady-state levels of the anti-apoptotic short form of FLIP $\left(\right.$ FLIP $\left._{S}\right)$, an inhibitor of caspase 8 activation, have been shown to decrease in response to $\mathrm{CHX}$-mediated translational inhibition, ${ }^{71}$ making the disappearance of FLIPS $_{S}$ one possible mechanism for the increased activation of caspase 8 under conditions of decreased protein synthesis. However, using two independent antibodies that recognize FLIP $_{S}$, we have failed to detect a significant decrease in expression of the FLIPs in response to CHX (not shown). Future work is required to elucidate the mechanisms by which inhibition of protein synthesis contributes to activation of caspase 8 and whether the virus-instigated inhibition of translation by PKR and RNaseL collaborates with caspase 8-directed activation of the apoptotic machinery to promote the death of virus-infected cells.

\section{Acknowledgments}

We thank Paul Spitz, Thanh-Hoai Dinh and Remy Choi for the excellent technical assistance.

\section{References}

1. Jacobs BL, Langland JO. When two strands are better than one: The mediators and modulators of the cellular responses to double-stranded RNA. Virology 1996; 219: 339-349.

2. Chu WM, Ostertag D, Li ZW, et al. JNK2 and IKKbeta are required for activating the innate response to viral infection. Immunity 1999; 11: 721-731.

3. Iordanov MS, Paranjape JM, Zhou A, et al. Activation of p38 mitogen-activated protein kinase and c-Jun $\mathrm{NH}(2)-$ terminal kinase by double-stranded RNA and encephalomyocarditis virus: Involvement of RNase L, protein kinase R, and alternative pathways. Mol Cell Biol 2000; 20: 617627.

4. Iordanov MS, Wong J, Bell JC, Magun BE. Activation of NFkappaB by double-stranded RNA (dsRNA) in the absence of protein kinase $\mathrm{R}$ and $\mathrm{RNase} \mathrm{L}$ demonstrates the existence of two separate dsRNA-triggered antiviral programs. Mol Cell Biol 2001; 21: 61-72.
5. Balachandran S, Kim CN, Yeh WC, Mak TW, Bhalla K, Barber GN. Activation of the dsRNA-dependent protein kinase, PKR, induces apoptosis through FADD-mediated death signaling. Embo J 1998; 17: 6888-6902.

6. Iordanov MS, Ryabinina OP, Wong J, et al. Molecular determinants of apoptosis induced by the cytotoxic ribonuclease onconase: Evidence for cytotoxic mechanisms different from inhibition of protein synthesis. Cancer Res 2000; 60: 19831994.

7. Liu D, Cardozo AK, Darville MI, Eizirik DL. Double-stranded RNA cooperates with interferon-gamma and IL-1 beta to induce both chemokine expression and nuclear factor-kappa Bdependent apoptosis in pancreatic beta-cells: Potential mechanisms for viral-induced insulitis and beta-cell death in type 1 diabetes mellitus. Endocrinology 2002; 143: 1225-1234.

8. Barber GN. Host defense, viruses and apoptosis. Cell Death Differ 2001; 8: 113-126.

9. Donze O, Dostie J, Sonenberg N. Regulatable expression of the interferon-induced double-stranded RNA dependent protein kinase PKR induces apoptosis and fas receptor expression. Virology 1999; 256: 322-329.

10. Kibler KV, Shors T, Perkins KB, et al. Double-stranded RNA is a trigger for apoptosis in vaccinia virus-infected cells. J Virol 1997; 71: 1992-2003.

11. Teodoro JG, Branton PE. Regulation of apoptosis by viral gene products. J Virol 1997; 71: 1739-1746.

12. Cuconati A, White E. Viral homologs of BCL-2: Role of apoptosis in the regulation of virus infection. Genes Dev 2002; 16: 2465-2478.

13. Schwarz EM, Badorff C, Hiura TS, et al. NF-kappaB-mediated inhibition of apoptosis is required for encephalomyocarditis virus virulence: A mechanism of resistance in p50 knockout mice. J Virol 1998; 72: 5654-5660.

14. Kerr JF, Wyllie AH, Currie AR. Apoptosis: A basic biological phenomenon with wide-ranging implications in tissue kinetics. Br J Cancer 1972; 26: 239-257.

15. Hengartner MO. The biochemistry of apoptosis. Nature 2000; 407: 770-776.

16. Rich T, Allen RL, Wyllie AH. Defying death after DNA damage. Nature 2000; 407: 777-783.

17. Savill J, Fadok V. Corpse clearance defines the meaning of cell death. Nature 2000; 407: 784-788.

18. Krammer PH. CD95's deadly mission in the immune system. Nature 2000; 407: 789-795.

19. Meier P, Finch A, Evan G. Apoptosis in development. Nature 2000; 407: 796-801.

20. Yuan J, Yankner BA. Apoptosis in the nervous system. Nature 2000; 407: 802-809.

21. Nicholson DW. From bench to clinic with apoptosis-based therapeutic agents. Nature 2000; 407: 810-816.

22. Locksley RM, Killeen N, Lenardo MJ. The TNF and TNF receptor superfamilies: Integrating mammalian biology. Cell 2001; 104: 487-501.

23. Chinnaiyan AM, O'Rourke K, Tewari M, Dixit VM. FADD, a novel death domain-containing protein, interacts with the death domain of Fas and initiates apoptosis. Cell 1995; 81: 505-512.

24. Boldin MP, Varfolomeev EE, Pancer Z, Mett IL, Camonis JH, Wallach D. A novel protein that interacts with the death domain of Fas/APO1 contains a sequence motif related to the death domain. J Biol Chem 1995; 270: 7795-7798.

25. Boldin MP, Goncharov TM, Goltsev YV, Wallach D. Involvement of MACH, a novel MORT1/FADD-interacting protease, in Fas/APO-1- and TNF receptor-induced cell death. Cell 1996; 85: 803-815. 
26. Muzio M, Chinnaiyan AM, Kischkel FC, et al. FLICE, a novel FADD-homologous ICE/CED-3-like protease, is recruited to the CD95 (Fas/APO-1) death-inducing signaling. Cell 1996; 85: 817-827.

27. Kischkel FC, Hellbardt S, Behrmann I, et al., Cytotoxicitydependent APO-1 (Fas/CD95)-associated proteins form a death-inducing signaling complex (DISC) with the receptor. Embo J 1995; 14: 5579-5588.

28. Muzio M, Stockwell BR, Stennicke HR, Salvesen GS, Dixit VM. An induced proximity model for caspase-8 activation. $J$ Biol Chem 1998; 273: 2926-2930.

29. Ferri KF, Kroemer G. Mitochondria-the suicide organelles. Bioessays 2001; 23: 111-115.

30. Ferri KF, Kroemer G. Organelle-specific initiation of cell death pathways. Nat Cell Biol 2001; 3: E255-263.

31. Wang $\mathrm{X}$. The expanding role of mitochondria in apoptosis. Genes Dev 2001; 15: 2922-2933.

32. Zou H, Li Y, Liu X, Wang X. An APAF-1.cytochrome c multimeric complex is a functional apoptosome that activates procaspase-9.J Biol Chem 1999; 274: 11549-11556.

33. Acehan, D, Jiang X, Morgan DG, Heuser JE, Wang X, Akey CW. Three-dimensional structure of the apoptosome: Implications for assembly, procaspase- 9 binding, and activation. Mol Cell 2002; 9: 423-432.

34. Srinivasula SM, Fernandes-Alnemri T, Zangrilli J, et al. The Ced-3/interleukin 1beta converting enzyme-like homolog Mch6 and the lamin-cleaving enzyme Mch2alpha are substrates for the apoptotic mediator CPP32. J Biol Chem 1996; 271: 27099-27106

35. Duan H, Orth K, Chinnaiyan AM, et al. ICE-LAP6, a novel member of the ICE/Ced-3 gene family, is activated by the cytotoxic $T$ cell protease granzyme B. J Biol Chem 1996; 271 : 16720-16724.

36. Srinivasula SM, Ahmad M, Fernandes-Alnemri T, Alnemri ES. Autoactivation of procaspase- 9 by Apaf-1-mediated oligomerization. Mol Cell 1998; 1: 949-957.

37. Cohen GM. Caspases: The executioners of apoptosis. Biochem J 1997; 326(Pt 1): 1-16.

38. Shi Y. Mechanisms of caspase activation and inhibition during apoptosis. Mol Cell 2002; 9: 459-470.

39. Luo X, Budihardjo I, Zou H, Slaughter C, and Wang X. Bid, a $\mathrm{Bcl} 2$ interacting protein, mediates cytochrome $\mathrm{c}$ release from mitochondria in response to activation of cell surface death receptors. Cell 1998; 94: 481-490.

40. Li H, Zhu H, Xu CJ, Yuan J. Cleavage of BID by caspase 8 mediates the mitochondrial damage in the Fas pathway of apoptosis. Cell 1998; 94: 491-501.

41. Wei MC, Zong WX, Cheng EH, et al. Proapoptotic BAX and BAK: A requisite gateway to mitochondrial dysfunction and death. Science 2001; 292: 727-730.

42. Korsmeyer SJ, Wei MC, Saito M, Weiler S, Oh KJ, Schlesinger PH. Pro-apoptotic cascade activates BID, which oligomerizes $\mathrm{BAK}$ or BAX into pores that result in the release of cytochrome c. Cell Death Differ 2000; 7: 1166-1173.

43. Krajewski S, Krajewska M, Reed JC. Immunohistochemical analysis of in vivo patterns of Bak expression, a proapoptotic member of the Bcl-2 protein family. Cancer Res 1996; 56: 28492855.

44. Griffiths GJ, Dubrez L, Morgan CP, et al. Cell damage-induced conformational changes of the pro-apoptotic protein Bak in vivo precede the onset of apoptosis. J Cell Biol 1999; 144: 903-914.

45. Nechushtan A, Smith CL, Lamensdorf I, Yoon SH, Youle RJ. Bax and Bak coalesce into novel mitochondria-associated clusters during apoptosis. J Cell Biol 2001; 153: 1265-1276.
46. Wang GQ, Gastman BR, Wieckowski E, et al. A role for mitochondrial Bak in apoptotic response to anticancer drugs. J Biol Chem 2001; 276: 34307-34317.

47. Wei MC, Lindsten T, Mootha VK, et al. tBID, a membranetargeted death ligand, oligomerizes BAK to release cytochrome c. Genes Dev 2000; 14: 2060-2071.

48. Balachandran S, Roberts PC, Kipperman T, et al. Alpha/beta interferons potentiate virus-induced apoptosis through activation of the FADD/Caspase- 8 death signaling pathway. J Virol 2000; 74: 1513-1523.

49. Bratton SB, Walker G, Srinivasula SM, et al. Recruitment, activation and retention of caspases -9 and -3 by Apaf- 1 apoptosome and associated XIAP complexes. Embo J 2001; 20: 998-1009.

50. Roy S, Bayly CI, Gareau Y, et al. Maintenance of caspase-3 proenzyme dormancy by an intrinsic "safety catch" regulatory tripeptide. Proc Natl Acad Sci USA 2001; 98: 6132-6137.

51. Thornberry NA, Rano TA, Peterson EP, et al. A combinatorial approach defines specificities of members of the caspase family and granzyme B. Functional relationships established for key mediators of apoptosis. J Biol Chem 1997; 272: 17907-17911.

52. Garcia-Calvo M, Peterson EP, Leiting B, Ruel R, Nicholson DW, Thornberry NA. Inhibition of human caspases by peptidebased and macromolecular inhibitors. J Biol Chem 1998; 273: 32608-32613.

53. Li F, Srinivasan A, Wang Y, Armstrong RC, Tomaselli KJ, Fritz LC. Cell-specific induction of apoptosis by microinjection of cytochrome c. Bcl-xL has activity independent of cytochrome c release. J Biol Chem 1997; 272: 30299-30305.

54. Srinivasula SM, Hegde R, Saleh A, et al. A conserved XIAPinteraction motif in caspase-9 and Smac/DIABLO regulates caspase activity and apoptosis. Nature 2001; 410: 112-116.

55. Meurs E, Chong K, Galabru J, et al. Molecular cloning and characterization of the human double-stranded RNA-activated protein kinase induced by interferon. Cell 1990; 62: 379-390.

56. Levin D, London IM. Regulation of protein synthesis: Activation by double-stranded RNA of a protein kinase that phosphorylates eukaryotic initiation factor 2. Proc Natl Acad Sci USA 1978; 75: 1121-1125.

57. Clemens MJ. Regulation of eukaryotic protein synthesis by protein kinases that phosphorylate initiation factor eIF-2. Mol Biol Rep 1994; 19: 201-210.

58. Chebath J, Benech P, Hovanessian A, Galabru J, Revel M. Four different forms of interferon-induced $2^{\prime}, 5^{\prime}$-oligo(A) synthetase identified by immunoblotting in human cells. $J$ Biol Chem 1987; 262: 3852-3857.

59. Zhou A, Hassel BA, Silverman RH. Expression cloning of 25A-dependent RNAase: A uniquely regulated mediator of interferon action. Cell 1993; 72: 753-765.

60. Silverman RH, Cayley PJ, Knight M, Gilbert CS, Kerr IM. Control of the ppp(a2'p)nA system in HeLa cells. Effects of interferon and virus infection. Eur J Biochem 1982; 124: 131138.

61. Wreschner DH, James TC, Silverman RH, Kerr IM. Ribosomal RNA cleavage, nuclease activation and 2-5A(ppp(A2' $\mathrm{p}) \mathrm{nA})$ in interferon-treated cells. Nucleic Acids Res 1981; 9: 1571-1581.

62. Gil J, Alcami J, Esteban M. Induction of apoptosis by doublestranded-RNA-dependent protein kinase (PKR) involves the alpha subunit of eukaryotic translation initiation factor 2 and NF-kappaB. Mol Cell Biol 1999; 19: 4653-4663.

63. Lee SB, Rodriguez D, Rodriguez JR, Esteban M. The apoptosis pathway triggered by the interferon-induced protein kinase PKR requires the third basic domain, initiates upstream of $\mathrm{Bcl}-$ 2, and involves ICE-like proteases. Virology 1997; 231: 81-88.

64. Srivastava SP, Kumar KU, Kaufman RJ. Phosphorylation of eukaryotic translation initiation factor 2 mediates apoptosis in 
response to activation of the double-stranded RNA-dependent protein kinase. J Biol Chem 1998; 273: 2416-2423.

65. Yeung MC, Chang DL, Camantigue RE, Lau AS. Inhibitory role of the host apoptogenic gene PKR in the establishment of persistent infection by encephalomyocarditis virus in U937 cells. Proc Natl Acad Sci USA 1999; 96: 11860-11865.

66. Castelli J, Wood KA, Youle RJ. The 2-5A system in viral infection and apoptosis. Biomed Pharmacother 1998 52: 386390.

67. Castelli JC, Hassel BA, Maran A, et al. The role of $2^{\prime}-5^{\prime}$ oligoadenylate-activated ribonuclease $\mathrm{L}$ in apoptosis. Cell Death Differ 1998; 5: 313-320.

68. Castelli JC, Hassel BA, Wood KA, et al. A study of the interferon antiviral mechanism: Apoptosis activation by the 2-5A system. J Exp Med 1997; 186: 967-972.

69. Zhou A, Paranjape J, Brown TL, et al. Interferon action and apoptosis are defective in mice devoid of 2',5'-oligoadenylate-dependent RNase L. Embo J 1997; 16 : 6355-6363.

70. Zhou A, Paranjape JM, Hassel BA, et al. Impact of RNase L overexpression on viral and cellular growth and death. $J$ Interferon Cytokine Res 1998; 18: 953-961.

71. Kreuz S, Siegmund D, Scheurich P, Wajant H. NF-kappaB inducers upregulate cFLIP, a cycloheximide-sensitive inhibitor of death receptor signaling. Mol Cell Biol 2001; 21:3964-3973.

72. Iordanov MS, Pribnow D, Magun JL, Dinh TH, Pearson JA, Magun BE. Ultraviolet radiation triggers the ribotoxic stress response in mammalian cells. J Biol Chem 1998; 273: 1579415803.

73. Iordanov MS, Magun BE. Loss of cellular $\mathrm{K}+$ mimics ribotoxic stress. Inhibition of protein synthesis and activation of the stress kinases SEK1/MKK4, stress-activated protein kinase/cJun NH2-terminal kinase 1, and p38/HOG1 by palytoxin. $J$ Biol Chem 1999; 274: 25801-25806. 